\title{
Copper Alloy-Impregnated Carbon-Carbon Hybrid Composites for Electronic Packaging Applications
}

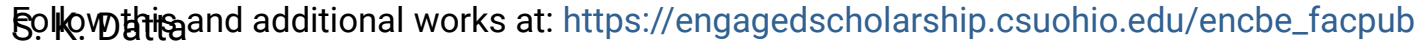

yeland State Npiversity science and Engineering Commons, and the Thermodynamics Commons storentpasa qreasarto this work benefit you? Let us know!

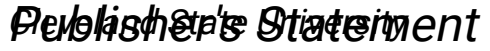

Gopyright 1999 ASM International. This paper was published in Metallurgical and Materials Eransalationateishomsigal Metallurgy and Materials Science, Vol. 30, Issue 1, pp. 175-181 and is made available as an electronic reprint with the permission of ASM International. One print or Wlechtrohic copy may be made for personal use only. Systematic or multiple reproduction, BFGoodrich Aerospace distribution to multiple locations via electronic or other means, duplications of any material in thiBesasenfor a fee or for commercial purposes, or modification of the content of this paper are BFofibfted. Aerospace

Available on publisher's site at: http://www.asminternational.org/portal/site/www/AsmStore/ ProductDetails/?vgnextoid=8d441774ef326210VgnVCM100000621e010aRCRD.

\section{Original Citation}

Datta, S.K., Tewari, S.N, Gatica, J.E., Shih, W., \& Bentsen, L. (1999). Copper Alloy-Impregnated CarbonCarbon Hybrid Composites for Electronic Packaging Applications. Metallurgical and Materials Transactions A: Physical Metallurgy and Materials Science 30, 175-181.

Repository Citation

Datta, S. K.; Tewari, Surendra N.; Gatica, Jorge E.; Shih, W.; and Bentsen, L., "Copper Alloy-Impregnated CarbonCarbon Hybrid Composites for Electronic Packaging Applications" (1999). Chemical \& Biomedical Engineering Faculty Publications. 6.

https://engagedscholarship.csuohio.edu/encbe_facpub/6

This Article is brought to you for free and open access by the Chemical \& Biomedical Engineering Department at EngagedScholarship@CSU. It has been accepted for inclusion in Chemical \& Biomedical Engineering Faculty Publications by an authorized administrator of EngagedScholarship@CSU. For more information, please contact library.es@csuohio.edu. 


\title{
Copper Alloy-Impregnated Carbon-Carbon Hybrid Composites for Electronic Packaging Applications
}

\author{
S.K. DATTA, S.N. TEWARI, J.E. GATICA, W. SHIH, and L. BENTSEN \\ Porous carbon-carbon preforms, based on three-dimensional networks of PAN (Polyacrylonitrile)- \\ based carbon fibers and various volume fractions of chemical vapor-deposited (CVD) carbon, were \\ impregnated by oxygen-free, high-conductivity (OFHC) $\mathrm{Cu}, \mathrm{Cu}-6 \mathrm{Si}-0.9 \mathrm{Cr}$, and $\mathrm{Cu}-0.3 \mathrm{Si}-0.3 \mathrm{Cr}$ (wt \\ pct) alloys by pressure infiltration casting. The obtained composites were characterized for their \\ coefficient of thermal expansion (CTE) and thermal conductivity $(K)$ along the through-thickness \\ and two in-plane directions. One composite, with a 28 vol pct $\mathrm{Cu}-0.3 \mathrm{Si}-0.3 \mathrm{Cr}$ alloy, showed out- \\ standing potential for thermal management applications in electronic applications. This composite \\ exhibited approximately isotropic thermal expansion properties $(\mathrm{CTE}=4$ to $6.5 \mathrm{ppm} / \mathrm{K})$ and thermal \\ conductivities $(k \geq 260 \mathrm{~W} / \mathrm{m} \mathrm{K})$.
}

\section{INTRODUCTION}

THE continued drive for system miniaturization in the electronics industry requires mounting several unpackaged electronic chips in close proximity to each other on a single substrate. Multichip modules, already in use in mainframe computers, are finding applications in workstations and high-performance avionic components. They require packaging materials with a high thermal conductivity $(k)$ and a coefficient of thermal expansion (CTE) which matches the low CTE values (4 to $6 \mathrm{ppm} / \mathrm{K}$ ) of the substrates (e.g., alumina) and devices (e.g., silicon and GaAs). ${ }^{[1,2]}$ Beryllium oxide or beryllium-beryllia composites are very attractive because of their very low density, outstanding thermal conductivity, and reasonably matching $\mathrm{CTE},{ }^{[3,4]}$ but their toxicity constitutes a serious problem, especially where machining is involved. ${ }^{[2]}$ Copper and aluminum have a very high thermal conductivity (398 and $247 \mathrm{~W} / \mathrm{m} \mathrm{K}$, respectively) but their CTE is much too large. However, their CTE can be brought down to 4 to $6 \mathrm{ppm} / \mathrm{K}$ by making composites containing appropriate volume fractions of lowCTE materials such as silicon carbide, aluminum nitride, or carbon. Aluminum and copper alloy composites containing carbon fibers, ${ }^{[2]}$ silicon carbide particles, ${ }^{[3]}$ diamond, ${ }^{[2]}$ and other reinforcements are being investigated for this application.

An aluminum-silicon carbide composite prepared by melt infiltration is presently a leading thermal management material for electronic applications. ${ }^{[2,3,4]}$ With 70 vol pct silicon carbide, this composite has a CTE of $6 \mathrm{ppm} / \mathrm{K}$ and a thermal conductivity of $110 \mathrm{~W} / \mathrm{m} \mathrm{K}^{[2]}$ (a value of $170 \mathrm{~W} / \mathrm{m} \mathrm{K}$ has been reported in the literature, ${ }^{[5]}$ but its original source is inaccessible).

A composite containing 67 vol pct graphite and an oxygen-free, high-conductivity (OFHC) copper matrix, pre-

S.K. DATTA, Graduate Student, S.N. TEWARI, Professor, and J.E. GATICA, Associate Professor, are with the Chemical Engineering Department, Cleveland State University, Cleveland, OH 44115. W. SHIH, is Product Manager, Super-Temp, BFGoodrich Aerospace, Santa Fe Springs, CA 90670. L. BENTSEN, Research Manager, R\&D, BFGoodrich Aerospace, Brecksville, OH 44141.

Manuscript submitted May 12, 1997. pared by hot pressing ${ }^{[6]}$ copper-coated graphite fibers, showed thermal conductivity values of $400 \mathrm{~W} / \mathrm{m} \mathrm{K}$ parallel to the fiber axis and $60 \mathrm{~W} / \mathrm{m} \mathrm{K}$ transverse to the fiber axis. The pressure infiltration-cast copper alloy-carbon fiber composite, ${ }^{[7,8]}$ examined recently, showed a low CTE (1.6 $\mathrm{ppm} / \mathrm{K})$ and good room-temperature mechanical properties. However, carbon fiber-reinforced composites have the following serious limitations. (1) Their thermal conductivity is highly anisotropic. As shown by Ilegbusi ${ }^{[9]}$ an improvement in thermal conductivity in the direction normal to the fiber axis is critical for the heat-removal efficiency in the system. The ideal thermal management material for electronic applications should have a high isotropic thermal conductivity. (2) The composites have a low, reasonably acceptable CTE parallel to the fiber axis, but their CTE normal to the fiber axis is very large, nearly equal to that of copper. ${ }^{[5]}$ (3) They suffer from "racheting" during thermal cycling, i.e., compressive and tensile plastic deformations occur during thermal cycling of the composites. (4) Melt infiltration does not yield a uniform fiber distribution across the entire specimen cross section; instead, "melt channels" invariably develop in the microstructure, causing fiber bunching. All these limitations are due to the fibrous nature of the graphite fiber reinforcement.

These problems can be eliminated by using a porous preform made of a three-dimensional network of carbon fibers for the pressure infiltration of copper melt. Currently, a copper-graphite composite is commercially available from UNOCAL-POCO (Decatur, Texas), with a CTE of $8.6 \mathrm{ppm} / \mathrm{K}$ (slightly larger than the optimum value of $6 \mathrm{ppm} / \mathrm{K}$ ), but its thermal conductivity is only $175 \mathrm{~W} / \mathrm{m} \mathrm{K}$. This research was aimed at developing a pressure infiltration-cast carboncopper alloy composite with high isotropic thermal conductivity (greater than $175 \mathrm{~W} / \mathrm{m} \mathrm{K}$ ) and a low CTE (about $6 \mathrm{ppm} / \mathrm{K})$.

\section{EXPERIMENTAL PROCEDURE}

The porous carbon-carbon (C-C) preforms were fabricated at BFGoodrich (Santa Fe Springs, CA), using a proprietary process to yield three types of preforms with various void fractions ( 23 to $46 \mathrm{pct}$ ) and pore sizes. Pore size distributions were determined by mercury porosimetry. 

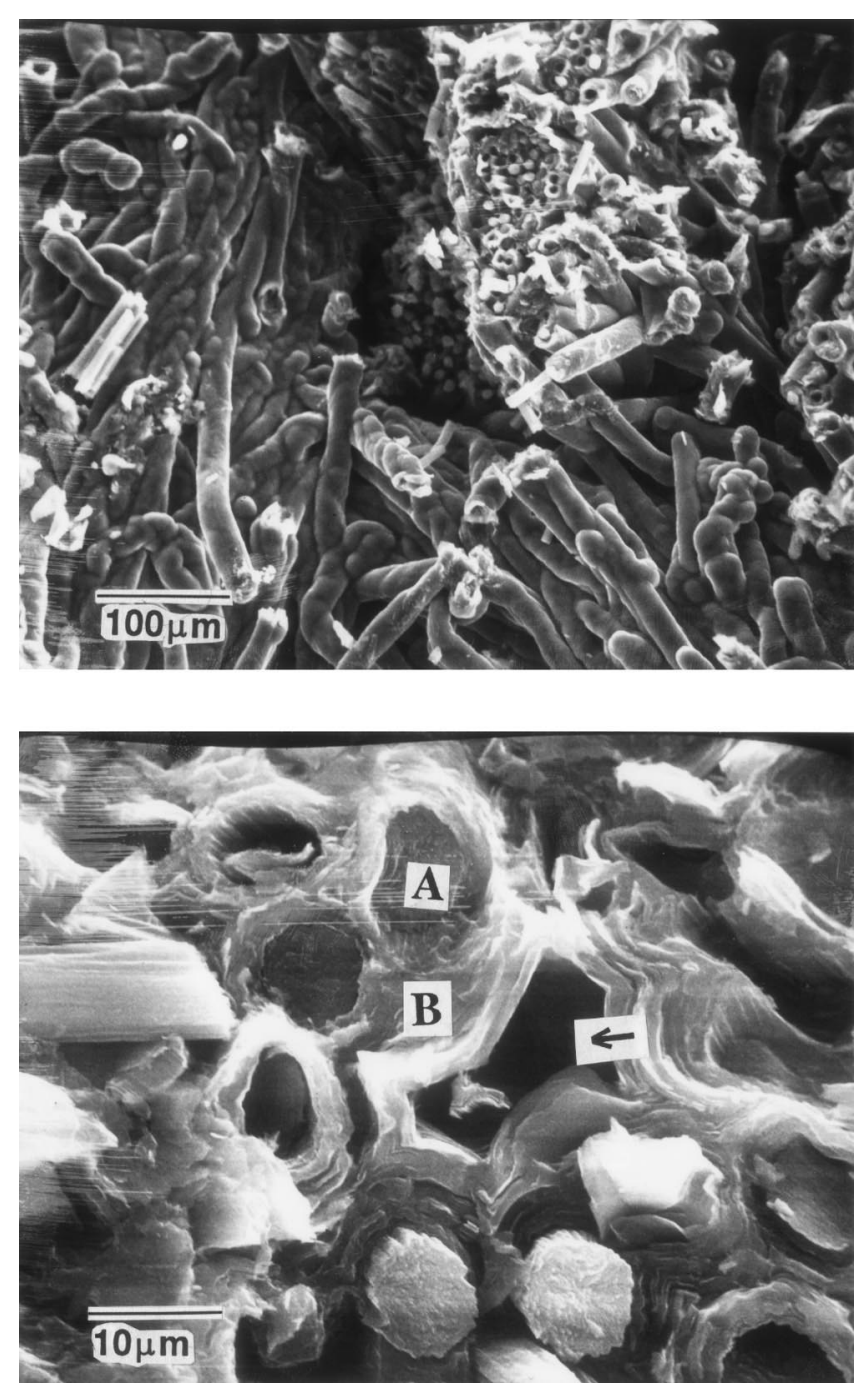

Fig. 1-Microstructure of porous carbon-carbon preforms.

The permeabilities of the preforms were determined by correlating water flow rates with the applied pressure gradient according to Darcy's law. The C-C preforms were infiltrated with three copper alloys: OFHC copper, Cu-6Si$0.9 \mathrm{Cr}$ (wt pct) and $\mathrm{Cu}-0.3 \mathrm{Cr}-0.3 \mathrm{Si}$ (wt pct). Chromium was added to increase the melt wettability. ${ }^{[9]} \mathrm{A}$ silicon addition was selected because it would improve the melt fluidity, and the formation of silicon carbide may result in reduced solidification shrinkage. When one mole of carbon and one mole of silicon combine to form one mole of silicon carbide, the volume expansion is approximately 58 pct. Such a volume expansion during the final stages of solidification helps to reduce the volume fraction of shrinkage porosity. During pressure casting, the prealloyed ingots, placed on top of the porous C-C preforms in an alumina crucible, were first melted under low-pressure $\left(\sim 10^{-2}\right.$ Torr $)$ conditions. The melt was superheated to approximately $200 \mathrm{~K}$ above its melting temperature. High-pressure ( 4 MPa) ultra-high purity argon gas was then rapidly introduced into the pressure casting chamber to force the melt into the pores of the preform. The specimens were allowed to solidify under pressure by switching off the induction power supply to the graphite susceptors surrounding the alumina crucible.

The microstructures of the C-C preforms and the infil- tration-cast composite specimens were examined by standard optical metallography and scanning electron microscopy (SEM). The linear thermal expansion of the composite was examined, in a flowing argon atmosphere within a temperature range from 300 to $700 \mathrm{~K}$, in a dilatometer in the through-thickness $(\mathrm{Z})$ and the in-plane (X and $\mathrm{Y}$ ) directions. The dilatometer was calibrated with a quartz specimen. Thermal diffusivities in the $\mathrm{X}, \mathrm{Y}$, and $\mathrm{Z}$ directions were measured by the laser-flash method. Thermal conductivities were estimated from the thermal diffusivities by using volume-averaged values of the heat capacity of the metal and the carbon constituents and an experimentally determined composite density.

\section{RESULTS AND DISCUSSION}

\section{A. Porous C-C Preforms}

\section{Microstructure}

Figure 1 shows a typical microstructure of the porous C$\mathrm{C}$ preform. The C-C preform is based on a three-dimensional network of PAN (Polyacrylonitrile) carbon fibers, into which carbon has been introduced by chemical vapor deposition techniques to obtain preforms with various void fractions and pore size distributions. Figure 1(a) contains two regions. In one region, the fibers are viewed mostly along their length. In the other region their head-on view is seen. The high-magnification view in Figure 1(b) shows the carbon fiber (marked as A) and the chemical vapordeposited (CVD) carbon that was deposited on its surface (marked as B). The fibers are about $10 \mu \mathrm{m}$ in diameter and occupy about 25 pct of the volume. The fraction porosity is controlled by the extent of carbon deposition by chemical vapor deposition. The CVD carbon for this sample is 3 to $4-\mu \mathrm{m}$ thick. A typical pore, marked by an arrow, is visible in this microstructure. The copper alloy was infiltrated into such pores.

\section{Mercury porosimetry}

Figure 2 shows the results of mercury porosimetry determinations for the three $\mathrm{C}-\mathrm{C}$ preforms examined in this study: C1-1, C41B, and SPC3P. Figures 2(a) and (b) show the percent total intrusion volume as a function of the pore diameter and the corresponding normalized pore volume distributions, respectively. Pores larger than $100 \mu \mathrm{m}$ were rarely observed in the $\mathrm{C}-\mathrm{C}$ preform microstructures. Therefore, the features corresponding to very large pores $\left(D_{p}>\right.$ $100 \mu \mathrm{m}$ ) appearing in Figures 2(a) and (b) are likely to be the artifacts resulting from the specimen preparation, e.g., cracks occurring on the specimen surface during machining. The smallest pores correspond to the $\mathrm{C} 41 \mathrm{~B}$ preform, while the largest pores were found in the C1-1 preform. The fraction of submicron pores is the largest in $\mathrm{C} 41 \mathrm{~B}$ and is the smallest in $\mathrm{C} 1-1$. The median pore diameters, listed in Table I, are based on the intruded volume, while the average pore diameters represent the relationship $4 V / A$, where $V$ is the total intrusion volume and $A$ is the total pore surface area. Bulk densities and the fraction porosities (based on the total mercury intrusion volume) were used, to obtain the skeletal densities. Table I shows that C1-1 and SPC3P have similar median pore diameters $(24.0$ and $27.5 \mu \mathrm{m}$ respectively) but SPC3P, with a larger fraction of submicron pores, has a 33-pct smaller average pore diameter (i.e., 0.06 


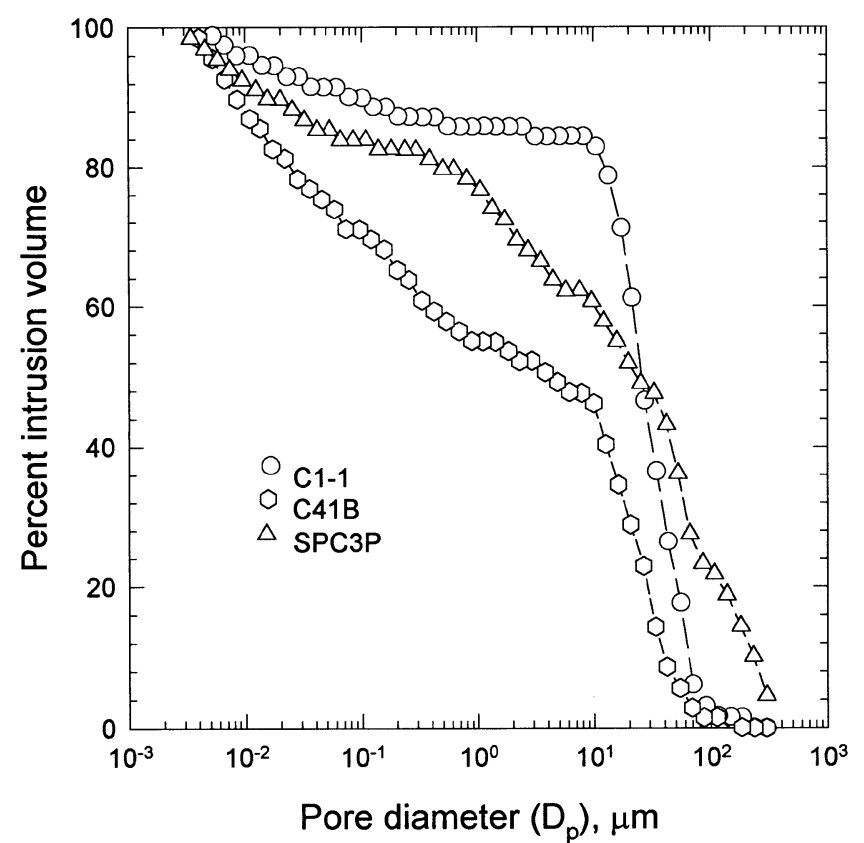

(a)

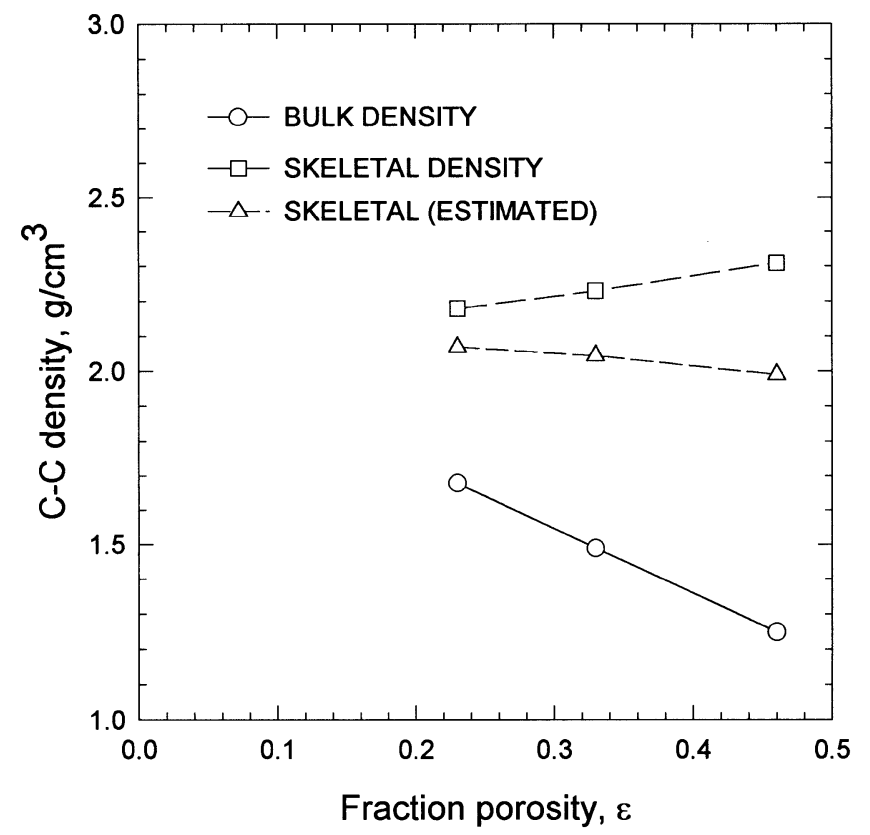

(c)

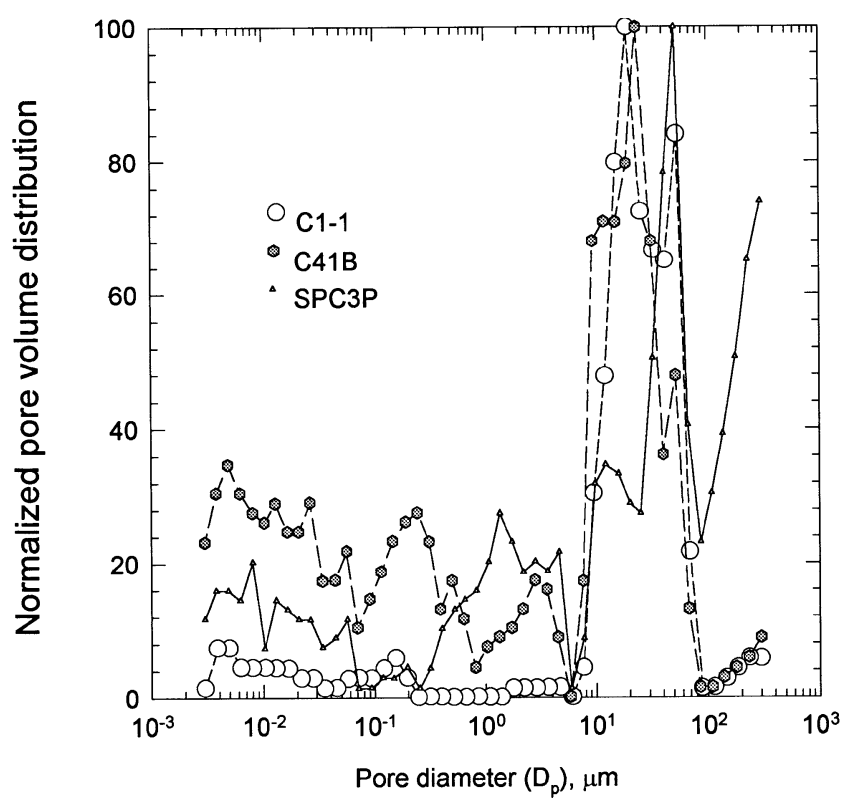

(b)
Fig. 2-Porosimetry determinations for porous C-C preforms: (a) intrusion curves, $(b)$ normalized pore volume distributions, and $(c)$ density vs fraction porosity.

Table I. Mercury Porosimetry Results for the Porous Carbon-Carbon Preforms

\begin{tabular}{lccccc}
\hline C-C Preform Type & $\begin{array}{c}\text { Median Pore Diameter } \\
D_{p}, \mu \mathrm{m}\end{array}$ & $\begin{array}{c}\text { Average Pore Diameter } \\
(4 \mathrm{~V} / \mathrm{A}), \mu \mathrm{m}\end{array}$ & $\begin{array}{c}\text { Bulk Density } \\
\rho_{b}, \mathrm{~g} / \mathrm{cm}^{3}\end{array}$ & $\begin{array}{c}\text { Skeletal Density } \\
\rho, \mathrm{g} / \mathrm{cm}^{3}\end{array}$ & $\begin{array}{c}\text { Fraction Porosity, } \\
\varepsilon\end{array}$ \\
\hline C1-1 & 24.0 & 0.09 & 1.49 & 2.23 & 0.33 \\
C41B & 4.2 & 0.03 & 1.68 & 2.18 & 0.23 \\
SPC3P & 27.5 & 0.06 & 1.25 & 2.31 & 0.46 \\
\hline
\end{tabular}

vs $0.09 \mu \mathrm{m})$. C41B has the smallest median $(4.2 \mu \mathrm{m})$ and average $(0.03 \mu \mathrm{m})$ pore diameters. The void fractions for SPC3P, C1-1, and C41B are 46, 33, and 23 pct, respectively.

Figure 2(c) plots the bulk and the skeletal densities of the three $\mathrm{C}$-C preforms as determined by mercury porosimetry. The skeletal densities obtained from mercury poro- simetry are based on the assumption that all the pores are interconnected. In the absence of isolated pores, the skeletal densities would be expected to increase with an increasing volume fraction of CVD carbon added to the preform, as indicated by the dotted line with triangular symbols. This line represents the estimated volume-averaged skeletal densities of the C-C preforms (assuming a 25 pct volume of 


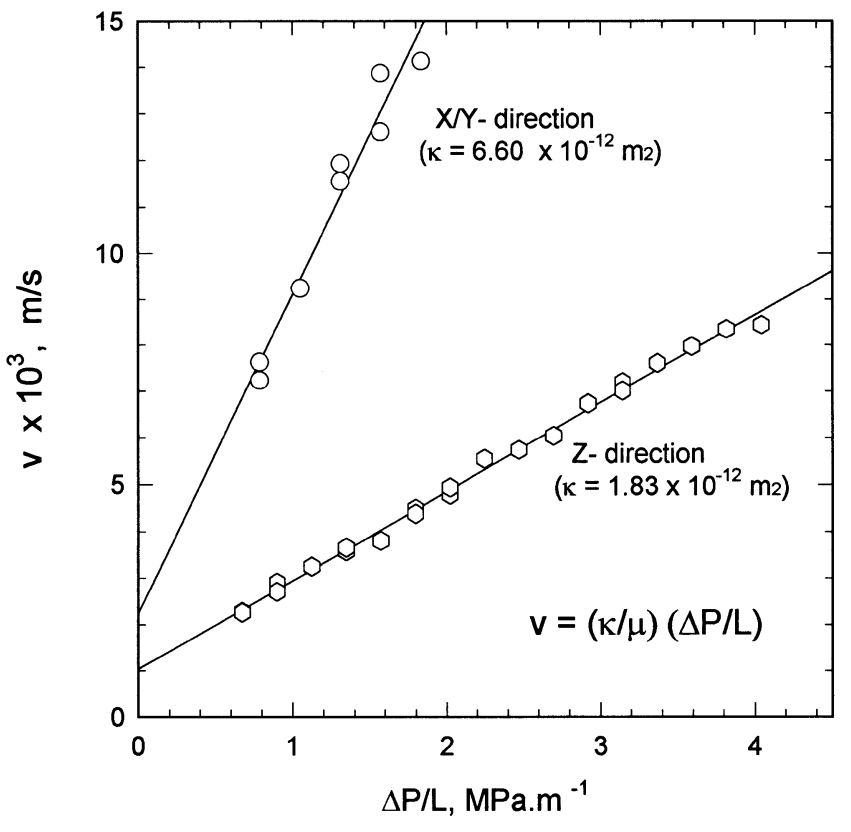

Fig. 3-Permeability determinations for C1-1 C-C preforms.
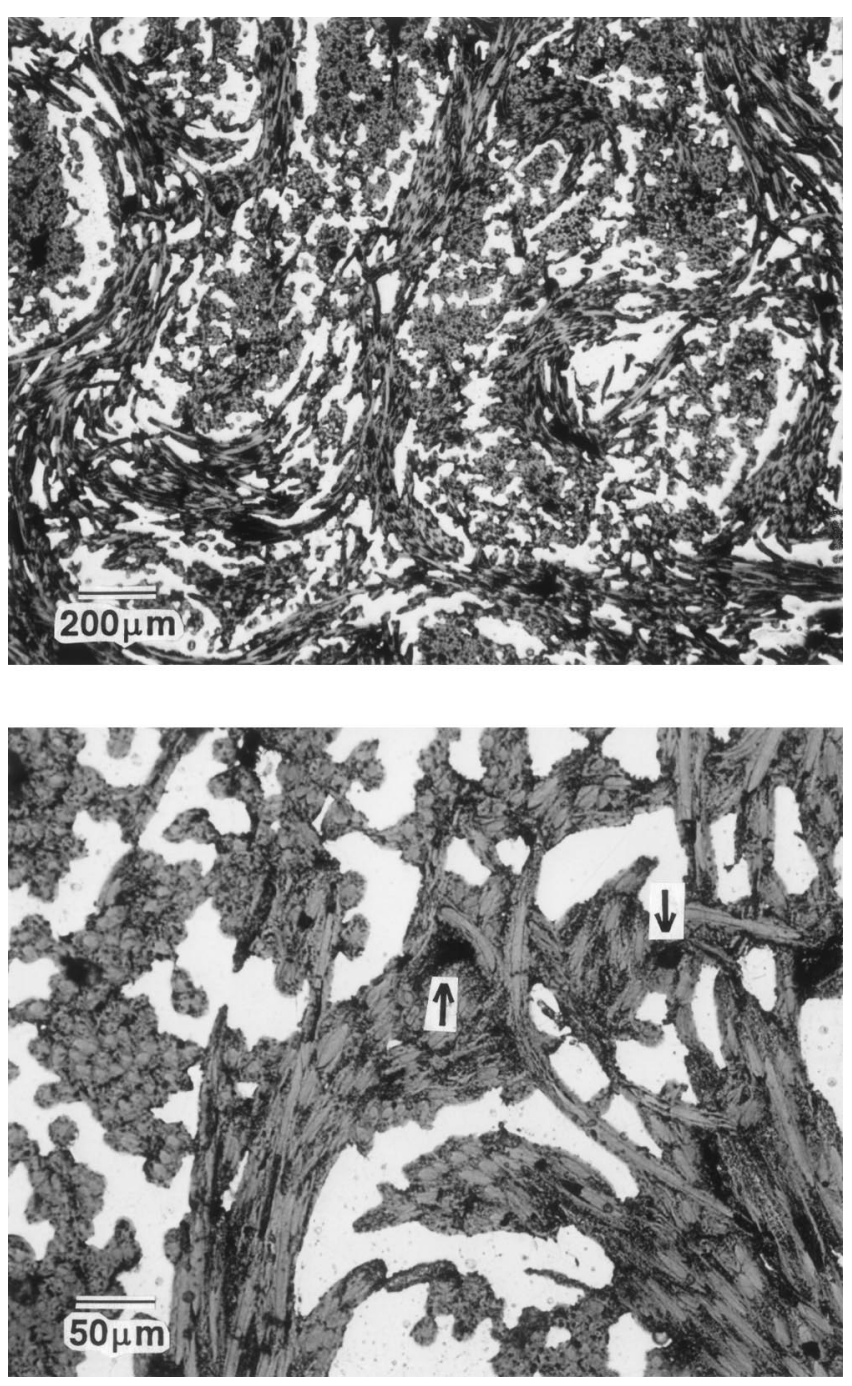

Fig. 4-Microstructure of pressure infiltrated cast $\mathrm{C}-\mathrm{Cu}$ composites. carbon fibers, with a density of $1.8 \mathrm{~g} / \mathrm{cm}^{3}$, and the rest being graphite, with a density of $2.2 \mathrm{~g} / \mathrm{cm}^{3}$ ). However, the skeletal density was actually observed to decrease with a decreasing pore fraction (rectangular symbols in Figure 2(c)). This suggests that the volume fraction of the isolated pores that are not interconnected increases with the increasing fraction of CVD carbon. This suggests that some of the interconnecting pores are occluded during the chemical vapor deposition process.

\section{Permeability}

Figure 3 shows water flow velocities as a function of the applied pressure gradient during a permeability experiment on $\mathrm{C} 1-1$. Flow velocities along the $\mathrm{Z}$ (through-thickness) and the X-Y (in-plane) directions are indicated in this figure. The goodness of fit exhibited by the linear correlation indicates the applicability of Darcy's law, $v=-(\kappa / \mu) \Delta P$, where $v$ represents the flow velocity, $\kappa$ is the permeability, $\mu$ is the dynamic viscosity of water $\left(9.62 \times 10^{-10} \mathrm{MPa} / \mathrm{s}\right)$, and $\Delta P$, is the external pressure gradient applied on the fluid. The permeability in the X-Y direction $\left(6.6 \times 10^{-12}\right.$ $\left.\mathrm{m}^{2}\right)$ is higher than that in the $\mathrm{Z}$ direction $\left(1.8 \times 10^{-12} \mathrm{~m}^{2}\right)$.

\section{B. Copper Alloy-Infiltrated C-C Composite}

\section{Microstructure}

Figure 4 shows the typical microstructure of a pressure infiltration-cast composite obtained by infiltrating a $\mathrm{Cu}-$ $6 \mathrm{Si}-0.9 \mathrm{Cr}$ alloy into a $\mathrm{C} 1-1 \mathrm{C}-\mathrm{C}$ preform. The white regions correspond to the copper alloy and the dark gray regions represent the carbon fibers. The three-dimensional weave of the fibers is evident by the longitudinal and transverse views of the fiber bundles in the low-magnification optical micrograph ( $c f$. Figure 4(a)). The uninfiltrated regions appear black and are more clearly visible at the higher magnification (marked by an arrow in Figure 4 (b)). Composites obtained with different C-C preform-alloy combinations showed similar features, except for the different amounts of uninfiltrated pores. The composite specimens were also examined by mercury porosimetry to determine the extent of infiltration as a function of the microstructural characteristics (pore size distribution, fraction porosity, etc.) of the $\mathrm{C}-\mathrm{C}$ preform and the alloying additives in the melt ( $\mathrm{Si}$ and $\mathrm{Cr}$ ).

\section{Mercury porosimetry}

Figure 5 shows the percent intrusion volume as a function of the pore diameter, obtained by mercury porosimetry performed on pressure infiltration-cast composite samples. The median and average pore diameters, bulk density, and pore fraction of the melt-infiltrated composite specimens are summarized in Table II. Figure 5(a) shows that there is a substantial decrease in the pore size after melt infiltration. As mentioned before, the pores larger than $100 \mu \mathrm{m}$ might be an artifact induced during the specimen preparation. Therefore, the actual average and median pore diameters must be slightly smaller than those reported in Table II. There is a substantial decrease in the median pore diameters after melt infiltration $(0.034 \mu \mathrm{m}$ for $\mathrm{Cu}-0.3 \mathrm{Si}-0.3 \mathrm{Cr}$ and $0.015 \mu \mathrm{m}$ for $\mathrm{Cu}-6 \mathrm{Si}-0.9 \mathrm{Cr}$ ) as compared to that of 24.0 $\mu \mathrm{m}$ for the C-C preform. However, the pressures used during casting $(\sim 4 \mathrm{MPa})$ do not appear sufficient to infiltrate the submicron pores in the preform. In general, for a given $\mathrm{C}-\mathrm{C}$ preform, the extent of infiltration was observed to in- 


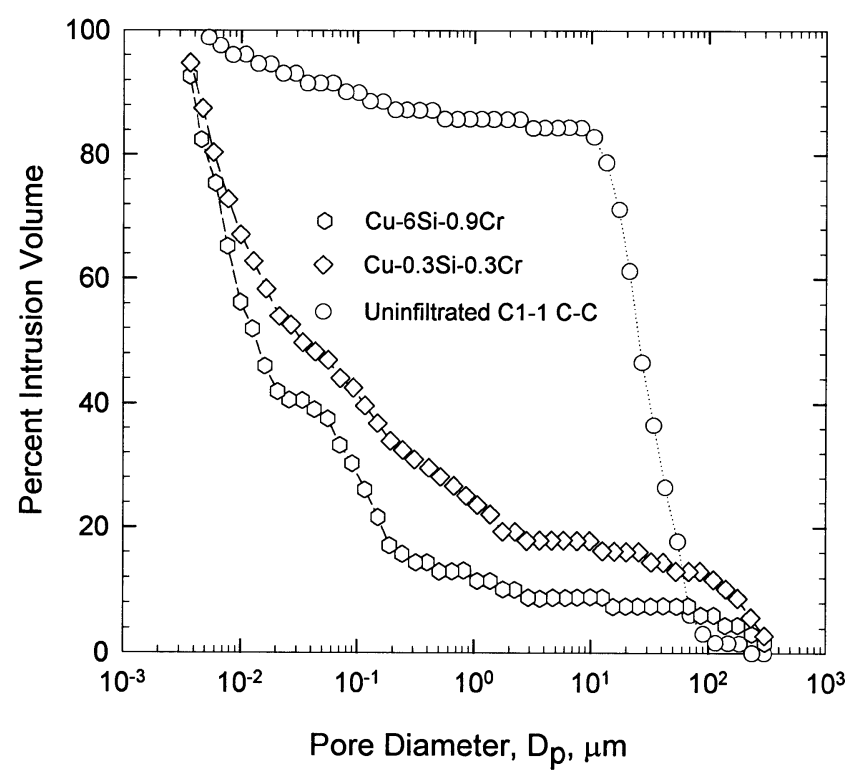

(a)

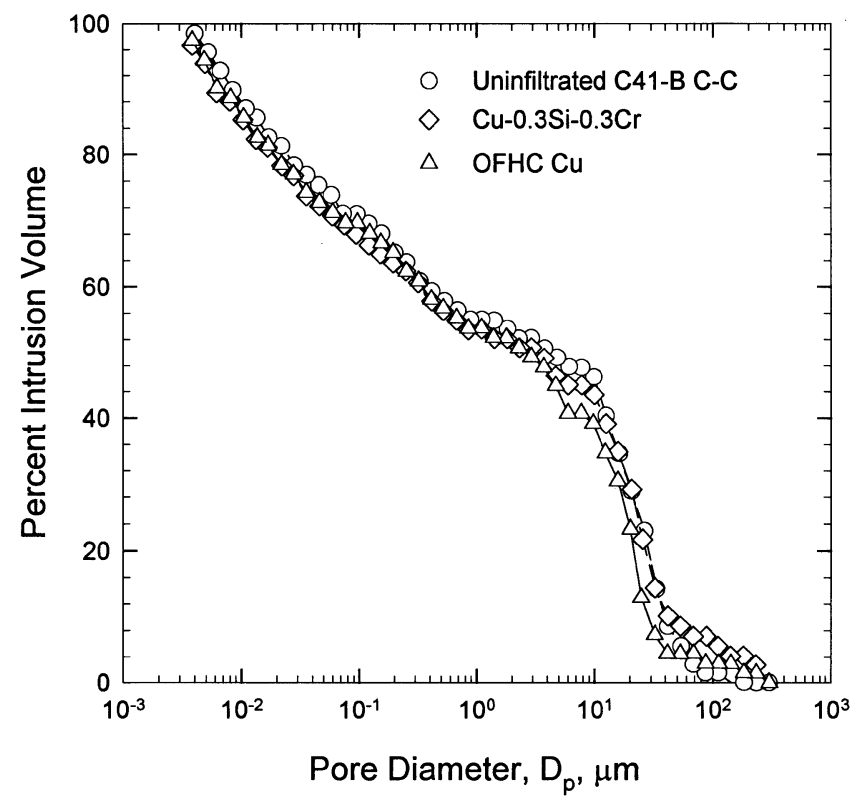

(c)

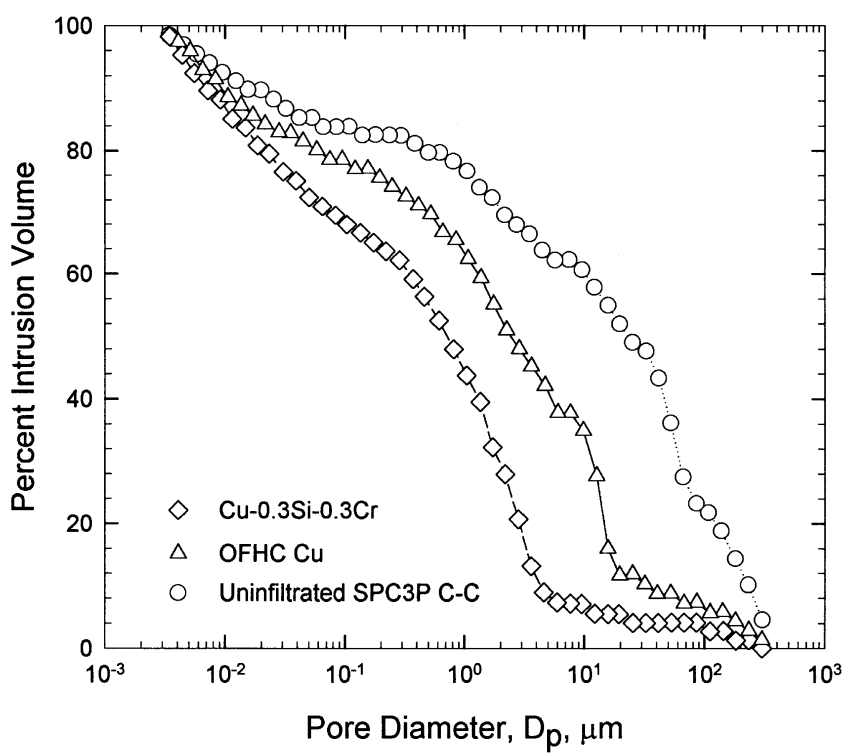

(b)

Fig. 5-Intrusion curves (porosimetry) for $\mathrm{C}-\mathrm{C}$ preforms and the corresponding pressure infiltrated cast $\mathrm{Cu}-\mathrm{C}$ composites: $(a) \mathrm{C} 1-1,(b)$ $\mathrm{SPC} 3 \mathrm{P}$, and $(c) \mathrm{C} 41-\mathrm{B}$.

Table II. Mercury Porosimetry Results for the Pressure Infiltration Cast Copper Alloy Composites

\begin{tabular}{lcccc}
\hline $\begin{array}{l}\text { Composite Type } \\
\text { (C-C + Alloy) }\end{array}$ & $\begin{array}{c}\text { Median Pore Diameter } \\
D_{p}, \mu \mathrm{m}\end{array}$ & $\begin{array}{c}\text { Average Pore Diameter } \\
(4 \mathrm{~V} / \mathrm{A}), \mu \mathrm{m}\end{array}$ & $\begin{array}{c}\text { Bulk Density } \\
\rho_{b}, \mathrm{~g} / \mathrm{cm}^{3}\end{array}$ & $\begin{array}{c}\text { Fraction Porosity, } \\
\varepsilon p\end{array}$ \\
\hline $\mathrm{C} 1-1+\mathrm{Cu}-6 \mathrm{Si}-3 \mathrm{Cr}$ & 0.015 & 0.011 & 4.28 & 0.07 \\
$\mathrm{C} 1-1+\mathrm{Cu}-0.3 \mathrm{Si}-0.3 \mathrm{Cr}$ & 0.034 & 0.013 & 4.01 & 0.12 \\
$\mathrm{C} 41 \mathrm{~B}+\mathrm{OFHC} \mathrm{Cu}$ & 2.89 & 0.028 & 2.12 & 0.22 \\
$\mathrm{C} 41 \mathrm{~B}+0.3 \mathrm{Si}-0.3 \mathrm{Cr}$ & 3.40 & 0.028 & 3.01 & 0.23 \\
$\mathrm{C} 41 \mathrm{~B}+\mathrm{Cu}-0.3 \mathrm{Si}-.3 \mathrm{Cr}$ & 0.763 & 0.033 & 3.58 & 0.19 \\
SPC3P + Cu-0.3Si-0.3Cr & 0.424 & 0.019 & 3.31 & 0.24 \\
SPC3P + Cu-0.3Si-0.3Cr & 0.731 & 0.023 & 2.67 & 0.23 \\
SPC3P + OFHC Cu & 2.59 & 0.038 & & 0.28 \\
\hline
\end{tabular}

crease in the following order: $\mathrm{OFHC} \mathrm{Cu}, \mathrm{Cu}-0.3 \mathrm{Si}-0.3 \mathrm{Cr}$, and $\mathrm{Cu}-6 \mathrm{Si}-0.9 \mathrm{Cr}$. Wetting angles $(\Theta)$ for the copper-chromium alloy melt on graphite have recently been reported to be 158,150 , and $45 \mathrm{deg}$ for the $\mathrm{OFHC} \mathrm{Cu}, \mathrm{Cu}-0.3 \mathrm{wt}$ pet $\mathrm{Cr}$, and $\mathrm{Cu}-0.9$ wt pet $\mathrm{Cr}$ alloys, respectively, ${ }^{[10]}$ Copper liquid-vapor surface energy $\left(\gamma_{L-V}\right)$ is about $1279 \mathrm{~mJ} / 2$. The minimum pore diameter which could be infiltrated by applying an external pressure of $4 \mathrm{MPa}$ can be estimated $\left(D_{p, \min } \gg 4 \gamma_{L-V} \operatorname{COS}(\theta) / P\right)$ to be $1.1 \mu \mathrm{m}$ for OFHC copper, and $1 \mu \mathrm{m}$ for $\mathrm{Cu}-0.3 \mathrm{Cr}$. Since the 0.9 wt pet $\mathrm{Cr}$ melt wets 
Table III. Coefficients of Thermal Expansion for the Copper Alloy Infiltrated Composites

\begin{tabular}{|c|c|c|c|c|c|c|c|}
\hline \multirow[b]{2}{*}{ Alloy } & \multirow{2}{*}{$\begin{array}{l}\text { C-C Preform } \\
\text { Type }\end{array}$} & \multirow{2}{*}{$\begin{array}{c}\text { Bulk Density } \\
\rho_{b}, \mathrm{~g} / \mathrm{cm}^{3}\end{array}$} & \multirow{2}{*}{$\begin{array}{l}\text { Metal Volume Fraction, } \\
\qquad \varepsilon_{M}\end{array}$} & \multirow{2}{*}{$\begin{array}{l}\text { Pore Volume Fraction, } \\
\qquad \varepsilon_{p}\end{array}$} & \multicolumn{3}{|c|}{ CTE, ppm/K } \\
\hline & & & & & $X$ & $\mathrm{Y}$ & $\mathrm{Z}$ \\
\hline \multirow[t]{3}{*}{ OFHC Cu } & $\mathrm{C} 41 \mathrm{~B}$ & 2.81 & 0.127 & 0.103 & 2.3 & 2.7 & 1.9 \\
\hline & C1-1 & 2.12 & 0.049 & 0.181 & 1.88 & - & 2.12 \\
\hline & SPC3P & 2.67 & 0.16 & 0.28 & - & 1.2 & 0.67 \\
\hline \multirow[t]{3}{*}{$\mathrm{Cu}-0.3 \mathrm{Cr}-0.3 \mathrm{Si}$} & C41B & 2.01 & 0.0317 & 0.193 & - & 1.58 & 1.8 \\
\hline & C1-1 & 4.01 & 0.28 & 0.05 & 6.5 & 6.5 & 4.1 \\
\hline & SPC3P & 3.55 & 0.26 & 0.20 & - & 3.7 & $4.55^{*}$ \\
\hline \multirow[t]{2}{*}{$\mathrm{Cu}-6 \mathrm{Si}-09 . \mathrm{Cr}$} & $\mathrm{C} 41 \mathrm{~B}$ & 2.18 & 0.056 & 0.174 & - & 3.2 & 2.0 \\
\hline & C1-1 & 4.28 & 0.31 & 0.02 & 10.2 & 10.05 & 6.1 \\
\hline
\end{tabular}

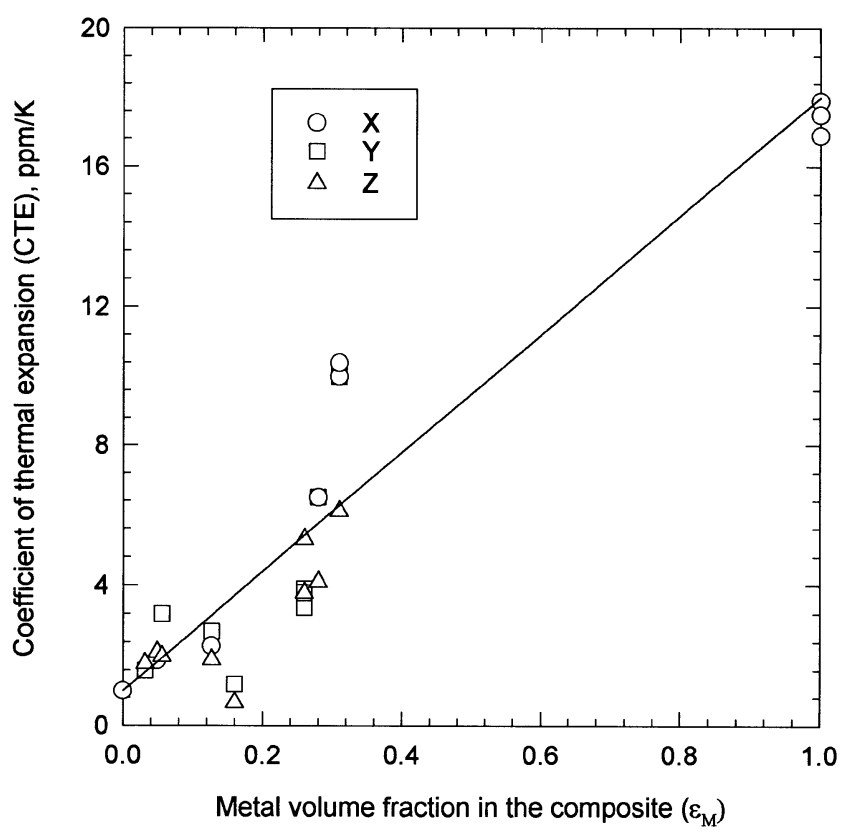

Fig. 6-CTE vs composite metal volume fraction $\left(\varepsilon_{M}\right)$.

graphite (i.e., $\theta<90 \mathrm{deg}$ ), a chromium addition to copper alloys should result in complete infiltration. Such a trend is qualitatively demonstrated in Figure 5. The quantitative differences between the expected and the observed extent of infiltration may be due to the uncertainties in the surface energy and wetting angle value, particularly in the presence of silicon in the melt.

Even though the median pore diameter of SPC3P was about the same as that of $\mathrm{C} 1-1$, its infiltration was not as efficient ( $c f$. the porosimetry measurements for the $\mathrm{Cu}$ $0.3 \mathrm{Si}-0.3 \mathrm{Cr}$ composites in Figures 5(a) and (b)). This is possibly due to the much larger fraction of submicron porosity present in SPC3P than in C1-1 (cf. Figures 2(a) and (b)). Figure 5(b) also shows that pure copper does not infiltrate as effectively as the $\mathrm{Cu}-0.3 \mathrm{Si}-0.3 \mathrm{Cr}$ alloy. The $\mathrm{C} 41-$ $\mathrm{B}$ preform has the maximum fraction of submicron porosity and, therefore, the smallest median and average pore diameters. It yields very little infiltration ( $c f$. Figure 5(c)).

\section{Coefficient of thermal expansion}

The CTE values for the melt-infiltrated samples, measured along the three directions $\mathrm{X}, \mathrm{Y}$, and $\mathrm{Z}$, and the corresponding matrix alloy and the $\mathrm{C}-\mathrm{C}$ preform types are given in Table III. The table also lists the bulk density and the metal $\left(e_{M}\right)$ and pore $\left(e_{p}\right)$ volume fractions. The OFHC $\mathrm{Cu}$, Cu-6Si-0.9Cr, and $\mathrm{Cu}-0.3 \mathrm{Si}-0.3 \mathrm{Cr}$ matrix alloys yielded approximately the same CTE, i.e., 17 to $18 \mathrm{ppm} / \mathrm{K}$. An examination of Table III reveals that C1-1 infiltrated with $\mathrm{Cu}-0.3 \mathrm{Si}-0.3 \mathrm{Cr}$ yields nearly isotropic thermal expansion properties, with a CTE ranging from 4 to $6.5 \mathrm{ppm} / \mathrm{K}$. As mentioned earlier, this is in the desired range for thermal management applications for multichip modules.

Figure 6 shows the CTE values for all the specimens examined in this study, as a function of the volume fraction of the copper alloy in the composite. The zero volumefraction value is for carbon (about $1 \mathrm{ppm} / \mathrm{K}$ ), and the unit volume-fraction values are those measured for the OFHC $\mathrm{Cu}, \mathrm{Cu}-6 \mathrm{Si}-0.9 \mathrm{Cr}$, and $\mathrm{Cu}-0.3 \mathrm{Si}-0.3 \mathrm{Cr}$ alloys (17 to 18 $\mathrm{ppm} / \mathrm{K})$. The straight line represents the linear regression through the data. As has been reported for the Al-SiC composites, ${ }^{[3]}$ here also, the volume-averaged values for the two constituents (metals and carbon) represent the CTE of these composites.

\section{Thermal conductivity}

Table IV gives the thermal diffusivity values along the $\mathrm{X}, \mathrm{Y}$, and $\mathrm{Z}$ directions for the composites, based on the preform $\mathrm{C} 1-1$ and two matrix alloys: $\mathrm{Cu}-6 \mathrm{Si}-0.3 \mathrm{Cr}$ and $\mathrm{Cu}-$ $0.3 \mathrm{Si}-0.3 \mathrm{Cr}$. The thermal diffusivity of OFHC copper is $1.15 \times 10^{-4} \mathrm{~m}^{2} / \mathrm{s}$. Alloying reduced the thermal diffusivity to $6.22 \times 10^{-6}$ for the $\mathrm{Cu}-6 \mathrm{Si}-0.9 \mathrm{Cr}$ and $4.46 \times 10^{-5} \mathrm{~m}^{2} / \mathrm{s}$ for the $\mathrm{Cu}-0.3 \mathrm{Si}-0.3 \mathrm{Cr}$. The bulk densities of the two composites are 4.28 and $4.01 \mathrm{~g} / \mathrm{cm}^{-3}$, respectively. The volume fractions of metal and carbon constituents for these composites are given in Table I. By volume-averaging the specific heat contributions from the metal $(0.386 \mathrm{~J} / \mathrm{g} \cdot \mathrm{K})$ and the carbon $(0.7 \mathrm{~J} / \mathrm{g} \cdot \mathrm{K})$, the specific heats of the composites are estimated to be 0.58 and $0.59 \mathrm{~J} / \mathrm{g} \cdot \mathrm{K}$, respectively. The thermal conductivity values listed in Table IV were obtained by using the bulk density, volume-averaged specific heat, and the thermal diffusivity. The $\mathrm{Cu}-0.3 \mathrm{Si}-0.3 \mathrm{Cr}$ composite showed significantly higher thermal conductivities than the $\mathrm{Cu}-6 \mathrm{Si}-0.9 \mathrm{Cr}$ composite. This would be expected because the addition of alloying elements, even though helpful for the melt infiltration, would degrade the thermal conductivity of the alloy. The $\mathrm{Cu}-0.3 \mathrm{Si}-0.3 \mathrm{Cr}$ composite has high thermal conductivity along all three directions, as compared with $\mathrm{C}-\mathrm{Cu}$ laminates based on P130 fibers, which had a high thermal conductivity $\left(260 \mathrm{~W} / \mathrm{m} \mathrm{K}^{[2]}\right)$ only in the in-plane direction.

\section{CONCLUSIONS}

This study indicates that the porous carbon preforms obtained by chemical vapor deposition of carbon into a threedimensional network of carbon fibers can be used to make 
Table IV. Thermal Diffusivity and Conductivity Values for the Copper Alloy Impregnated C1-1 Preform

\begin{tabular}{|c|c|c|c|c|c|c|}
\hline \multirow[b]{2}{*}{ Thermal Property } & \multicolumn{3}{|c|}{$\mathrm{Cu}-6 \mathrm{Si}-0.9 \mathrm{Cr}$} & \multicolumn{3}{|c|}{$\mathrm{Cu}-0.3 \mathrm{Si}-0.3 \mathrm{Cr}$} \\
\hline & $\mathrm{X}$ & $\mathrm{Y}$ & $\mathrm{Z}$ & $\mathrm{X}$ & $\mathrm{Y}$ & Z \\
\hline Diffusivity $(a) \times 10^{4}, \mathrm{~m}^{2} / \mathrm{s}$ & 0.937 & 0.827 & 0.853 & 1.128 & 1.173 & 2.01 \\
\hline Conductivity $(k), \mathrm{W} / \mathrm{m} \mathrm{K}$ & 236 & 208 & 215 & 261 & 271 & 465 \\
\hline
\end{tabular}

metal-matrix composite for thermal management materials for electronic applications. The copper alloy $(\mathrm{Cu}-0.3 \mathrm{Si}-$ $0.3 \mathrm{Cr}$, wt pct) infiltrated composites show a high thermal conductivity $(k>250 \mathrm{~W} / \mathrm{m} \mathrm{K})$, both in the in-plane direction and in the through-thickness direction. They also possess a nearly isotropic thermal coefficient of expansion, ranging from 4 to $6.5 \mathrm{ppm} / \mathrm{K}$, making them ideally suited for $\mathrm{Si} / \mathrm{GaAs} / \mathrm{AlO}_{2}$ substrates.

\section{ACKNOWLEDGMENTS}

This research was supported by a grant from the Ohio Aerospace Institute (Cleveland, OH). Appreciation is expressed to the NASA-Lewis Research Center for providing access to the mercury porosimetry analysis. The authors also acknowledge Professor Hasselman, Virginia Polytechnic Institute, for the laser-flash thermal diffusivity determinations.

\section{REFERENCES}

1. Metals Handbook, 9th ed., ASM, Materials Park, OH, vol. 3, 1980.

2. C.Z. Zweben: J. Met., 1992, vol. 44 (7), pp. 15-23.

3. M.K. Premkumar, W.H. Hunt, Jr., and R.R. Sawtell: J. Met., 1992, vol. 44 (7), pp. 24-29.

4. Advanced Materials and Processes, 1995, Oct., p. 8.

5. D. Maass and M. Makwinski: 6th Int. SAMPE Electronicsference, Honolulu, HI. June 22-25, 1992.

6. D.L. McDanels and J.O. Diaz: NASA TM-102328, 1989.

7. S.M. DeVincent: NASA Contractor Report 187143, NASA, Washington, DC, 1991.

8. D.L Ellis and D.L. McDanels: Metall. Trans. A, 1993, vol. 24A, pp. 43-52.

9. O.J. Ilegbusi: "Heat Transfer in Electronic System with Metal-Matrix Composite Heat Sink," ASME-93-WA/EEP-28, ASME, Fairfield, NJ, 1993.

10. S.M. DeVincent, D.L. Ellis, and G.M. Michal: "Graphite/Copper Alloy Interfacial Energies Determined Using the Sessile Drop Method,' NASA Contractor Report 187087, NASA-Lewis Research Center, Cleveland, OH, 1991. 